\title{
破壊力学を適用した補修用積層化樹脂材の 界面応力解析と材料設計
}

\author{
宮本 文穗 ${ }^{* 1}$ ・阿山 泰久 ${ }^{* 2}$ ・中西 誉*3 ・若原 直樹*4
}

\begin{abstract}
概 要 本研究は, コンクリート構造物の補修に用いられる積層化樹脂材について, 合理的な材料設計を行うことを目的と して, 積層化樹脂材界面の力学的挙動の評価と力学的な機能性を表す指標の確立についての検討を行ったものである。すなわ ち，まず積層化樹脂材について，従来の研究と異なった観点からの材料設計手法の検討として，界面上のき裂を考慮した破壊 力学的観点からの力学的挙動の評価および設計指標の検討を行い, さらに従来より著者らが提案している設計指標の改良を 行ったうえで, 両者を結合することにより, 積層化樹脂材の最適材料設計手法について独自の提案を行っている。その結果,

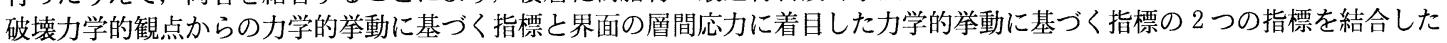
材料設計を行えば，さらに合理的な材料設計が行えることを示した。
\end{abstract}

キーワード : コンクリート構造物, 補修, 積層化樹脂材, FEM 解析, 界面応力, 応力拡大係数, 材料設計

\section{1. 緒 言}

近年, 材料に対する要求が多様化するなかで種々の性 能を有する新材料が開発され，建設分野に利用されつつ ある。しかし, 現状では, その材料選定フローが十分に 確立されているとは言い難いため, 主に経済性に重点を 置いた材料選定が優先され, 新材料の使用が見送られる 場合がみられる。その原因のひとつとして, 各種材料の 比較を行うための材料特性のフォーマットに統一がとれ ていないことが挙げられる。また, 材料に求められる性 能が多種多様化してきたため, 材料選定についてもそれ と同様に複雑化してきたことも挙げられる。これらのこ とより, 各種材料の比較・検討が行える合理的な選定基 準の確立が望まれている ${ }^{1)}$ 。従来より, 著者ら ${ }^{2)}$ はコン クリート構造物の補修に用いられる積層化樹脂材を対象 として，その材料選定を耐候性，防水性などといった材 料学的観点 ${ }^{3), 4)}$ からのみならず, 界面の剝離防止など といった力学的観点からの検討が必要と考え, 積層化樹 脂材界面の力学的挙動の評価と力学的な機能性を表す指 標の確立についての検討を行ってきている。

本研究は, コンクリート補修用積層化樹脂材界面の力 学的挙動の評価に基づく合理的な材料設計を行うことを

* 1 山口大学教授 工学部知能情報システム工学科(正会員) $* 2$ (株)大林組 大阪支店

*3 神戸大学大学院 自然科学研究科博士前期課程(正会員) $* 4$ コニシ(株)大阪研究所
目的として，まず積層化樹脂材について，従来の研究と は異なった観点からの材料選定指標の検討として, 界面 上のき裂を考慮した破壊力学の適用による応力拡大係数 などに基づく力学的挙動の評価および選定指標の確立を 行い, この指標と界面の層間応力に着目した力学的挙動 に基づく従来の選定指標の 2 つの指標を結合することに より, 積層化樹脂材の合理的な材料設計手法についての 提案を行うものである。

本研究の流れを図-1に示す。本研究では, 積層化樹 脂材の材料設計における力学的要求性能として界面で破 壊しない(はがれない)という設定を行い, 従来の研究2) よりさらに実際的なモデルとして母材（モルタル）にひ び割れが発生している場合を対象とし, 外力として曲げ を受ける場合と温度変化を受ける場合を考えた。そし て, 界面における力学的挙動の検討対象として, 母材に ひび割れを有する 3 層塗布供試体を用い, 従来の研究 2$)$ より得られている実験デー夕を基に層間せん断ばね定数 を決定し, 2 次元有限要素 (FEM) 解析を用いて層間せ ん断応力分布およびモルタル (母材) 表面の応力分布の 評価を行った。

次いで, 力学的要求性能に基づく材料選定指標の検討 として, まず従来の研究 $\left.{ }^{2}\right) て ゙$ 考案された評価指標 $A \tau$ に ついて, その破壊に対する限界值 $A \tau_{c}$ に関する実験を 行うことにより, $A \tau_{c}$ を考慮した材料選定指標 $\alpha$ の検討 を行った。さらに, 従来の研究とは異なった観点からの 検討として積層化樹脂材界面に破壊力学の考え方を導入 


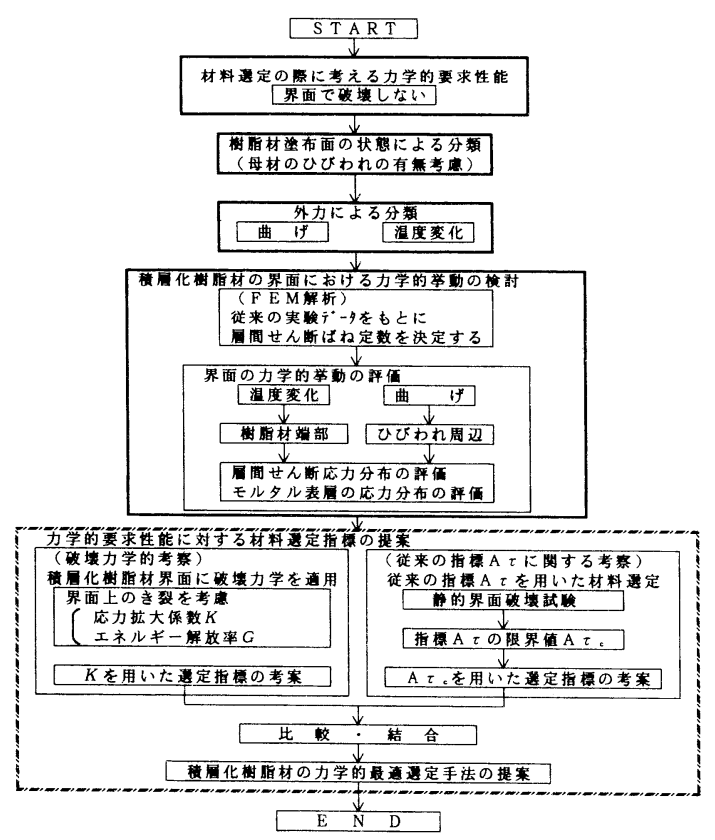

図-1 本研究全体のフロー

し，積層化樹脂材界面にき裂あるいは破損が生じること を想定した材料選定についても検討するため，応力拡大 係数 $K$ を用いた材料選定指標 $\Phi$ 検討し，これを用い た材料選定の検討を行っている。最後に, 両者を結合し た力学的材料設計手法の考え方を提案し，これに基づく 材料選定例を示した。

2. 破壊力学を適用した積層化樹脂材界面 の力学的挙動の評価

\section{1 解析手法}

従来の著者らの研究 2 では, 母材にひび割れ等が存在 しない状態で平面骨組解析手法および微分方程式と実験 を併用して樹脂材界面における力学的挙動を解析した。 しかし，母材にひび割れを有する，より実際のコンク リート構造物に近いモデルを対象とする場合, 前述 $2 つ$ の解析手法では解析が不可能となる。このため, 本研究 では界面応力の解析に 2 次元 FEM 解析手法の適用を試 みた。本研究で扱う供試体モデルは, モルタル厚に対し 樹脂材厚がかなり小さく, その剛性の違いを考慮した解 析手法を用いなければ，所定の精度を得ることができな いと考えられる。そこで, 本研究では, まず図一2のよ うに供試体全体を 3 角形要素と 4 角形要素によりモデル 化し，全体を大まかなメッシュで解析した後，図一2の 網掛け部分をZooming して取り出し, さらに細かく要 素分割して, Zooming 面に全体の解析で得られた節点 変位を強制変位として与えることにより樹脂材端部およ
びモルタルのひび割れ近傍の応力集中を解析する手法を 用いた。この 2 段階の解析手法を用いることにより, 全 体モデルを細かく要素分割する必要がなくなり計算時間 の短縮がはかられ, また, 必要な部分の応力, 層間せん 断応力を精度よく求めることができるという利点があ る。また，モルタルと樹脂材および樹脂材間の界面には 図-3に示す Bond-link 要素5),6)を導入し，それぞれ の界面の接着特性を評価した。

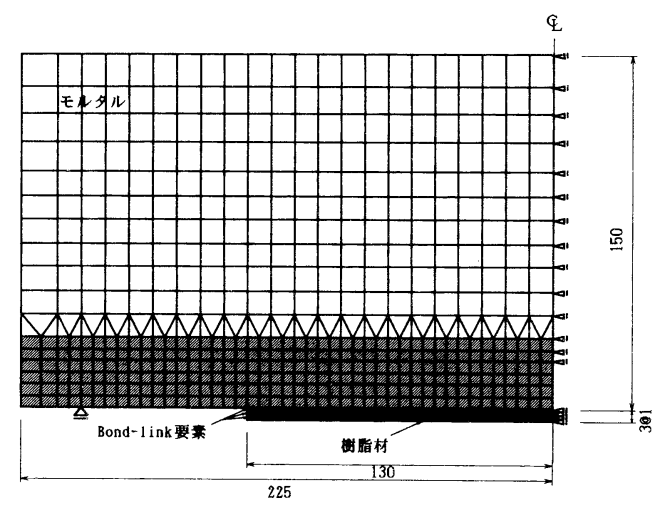

図-2 要素分割 (単位 $\mathrm{mm}$ )

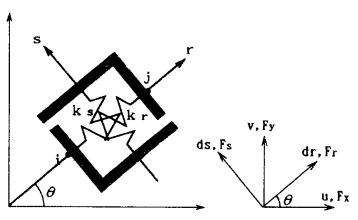

図-3 Bond-link 要素

\section{2 破壊力学の概要}

破壊力学は, 通常均一材のき裂近傍の応力解析あるい は材料設計に適用される。一般に均一材中のき裂破壊 は, 図-4に示す 3 種類の基本変形モードに分類でき, そのき裂先端の応力場は, それぞれのモードに対応して 以下のように与えられ，また，それぞれに対応する応力

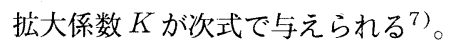

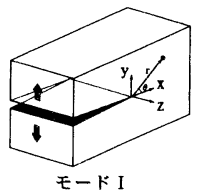

(き埕開口)

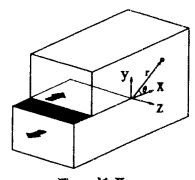

モート II

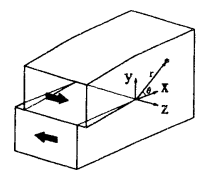

モードIII
図一4 破壊モード

$$
\text { モード I : }\left\{\begin{array}{c}
\sigma_{x} \\
\sigma_{y} \\
\tau_{x y}
\end{array}\right\}=\frac{K_{I}}{\sqrt{2 \pi r}} \cos \frac{\theta}{2}\left\{\begin{array}{l}
1+\sin \frac{\theta}{2} \sin \frac{3}{2} \theta \\
1-\sin \frac{\theta}{2} \sin \frac{3}{2} \theta \\
\sin \frac{\theta}{2} \cos \frac{3}{2} \theta
\end{array}\right\}
$$




$$
\begin{aligned}
& \text { モード II }:\left\{\begin{array}{c}
\sigma_{x} \\
\sigma_{y} \\
\tau_{x y}
\end{array}\right\}=\frac{K_{\Pi}}{\sqrt{2 \pi r} \times} \\
& \left\{\begin{array}{c}
\sin \frac{\theta}{2} \cos \frac{\theta}{2} \cos \frac{3}{2} \theta \\
-\sin \frac{\theta}{2}\left(2+\cos \frac{\theta}{2} \cos \frac{3}{2} \theta\right) \\
\cos \frac{\theta}{2}\left(1-\sin \frac{\theta}{2} \sin \frac{3}{2} \theta\right)
\end{array}\right\} \\
& \text { モードIII: }\left\{\begin{array}{c}
\tau_{x z} \\
\tau_{y z}
\end{array}\right\}=\frac{K_{\Pi}}{\sqrt{2 \pi r}}\left\{\begin{array}{c}
-\sin \frac{\theta}{2} \\
\cos \frac{\theta}{2}
\end{array}\right\}
\end{aligned}
$$

ただし， $r, \theta$ は，図-4のき裂先端からの距離および角 度を表す。

き裂が任意の負荷を受ける場合は，一般に混合モード となるが，この場合は，それぞれのモードに対応する応 力場の重稀わせが成立すると考える。また，き裂先端 近傍の変位場も同様に応力拡大係数を用いて表すことが でき，混合モードの重ね合わせも同様に成立する。した がって, き裂先端近傍の応力場および変位場はすべて相 似となり, 応力拡大係数が求まれば応力および変位状態 が一意的に決まることになる。それゆえ，この応力拡大 係数が破壊力学の主要なパラメー夕となる。一方, 応力 拡大係数之関連づけられるエネルギー開放率 $G$ もき裂 進展に伴う全ポテンシャルエネルギーの減少を評価する パラメータとして使われる。

以上は均一材中のき裂進展問題を対象としたものであ り, 本研究ではこの破壊力学パラメー夕を積層化樹脂材 界面に適用することを考える必要がある。異種材界面上 のき裂進展問題に対する破壊力学パラメー夕は, 均一材 のそれをそのまま適用することはできず，別途，以下に 示すような界面の破壊力学パラメー夕を適用する必要が ある ${ }^{8), 9) 。 ~}$

まず，2つの等方性材料が接合された界面上のき裂を 考える。図一5に示すようにそれぞれの材料を材料 1 , 材 料 2 とし, その弾性係数, せん断弾性係数, ポアソン比 をそれぞれ $E_{i}, \mu_{i}, v_{i}(i=1,2)$ とする。2つの材料の組 み合わせにより決まる材料定数 $\varepsilon$ を式 (4)のように定義 し, 図-5の $\theta=0^{\circ}$ の界面上の応力分布を示すと式 (6) のように表される。

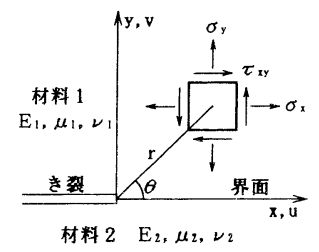

図一5 界面き裂先端の座標系と応力の定義

$$
\begin{aligned}
& \varepsilon=\frac{1}{2 \pi} \ln \left(\frac{\frac{\chi_{1}}{\mu_{1}}+\frac{1}{\mu_{2}}}{\frac{\chi_{2}}{\mu_{2}}+\frac{1}{\mu_{1}}}\right) \\
& \chi_{i}=\frac{3-\nu_{i}}{1+\nu_{i}} \quad(i=1,2) \quad \text { (平面応力) } \\
& {\left[\sigma_{y}+i \tau_{x y}\right]_{\theta=0}=\frac{K_{1}+i K_{2}}{\sqrt{2 \pi r}}\left(\frac{r}{l}\right)^{i \varepsilon}}
\end{aligned}
$$

ここで, $K_{1}+i K_{2}$ は界面き裂先端の複素応力拡大係数 であり, 上式から発生応力は, 振動特異性を有し, き裂 先端の極近傍で振動しつつ, その包絡線が $r-\frac{1}{2}$ の形で 特異性を呈することがわかる。なお，この場合の $K_{1}$, $K_{2}$ は均一材中のき裂破壊のモードI およびモードII の 応力拡大係数 $K_{\mathrm{I}}, K_{\mathrm{II}}$ 之異なり, 積層化樹脂材界面に 適用する必要があるためモード I と II の基本変形モー ドと必ずしも対応しない。それゆえ，ここでは界面き裂 先端の応力拡大係数を算用数字を用いて $K_{1}, K_{2}$ 之記す

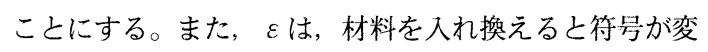
わり，また， $2 つ の$ 材料を同一とすると $\varepsilon=0$ となり, 式 (6) は均一材の場合之同一の応力拡大係数 $K_{1}=K_{\mathrm{I}}$, $K_{2}=K_{\text {II }}$ に帰着する。なお, 式 $(6)$ の $l$ は, 振動項を無 次元化するための基準長さであり, 通常き裂の全長をと るものとする。本研究では, 2 次元 FEM 解析により得 られたき裂近傍の応力を用い, 次式に示す外挿法を用い て応力拡大係数およびエネルギー開放率を求める手法 ${ }^{8)}$ を用いることとした。

$$
\begin{aligned}
& K_{1}=\lim _{r \rightarrow 0} \sqrt{2 \pi r}\left(\sigma_{y} \cos Q+\tau_{x y} \sin Q\right) \\
& K_{2}=\lim _{r \rightarrow 0} \sqrt{2 \pi r}\left(\tau_{x y} \cos Q-\sigma_{y} \sin Q\right) \\
& Q=\varepsilon \ln (r / l), l=2 a \\
& G=\frac{1}{16 \cosh ^{2}(\varepsilon \pi)}\left\{\frac{\chi_{1}+1}{\mu_{1}}+\frac{\chi_{2}+1}{\mu_{2}}\right\}\left(K_{1}^{2}+K_{2}^{2}\right)
\end{aligned}
$$

なお，上式中の $a$ はき裂長さである。

\section{3 積層化樹脂材界面への破壊力学の適用}

前述した界面での破壊力学パラメー夕を従来の実験供 試体 ${ }^{2)}$ に適用し, 応力拡大係数およびエネルギー開放率 を求めた。ここでは界面上にき裂が生じたとして，その 後のき裂進展, 界面破壊を考慮した材料設計を考えるも のとし, 界面き裂の影響を考慮した積層化樹脂材の力学 的挙動を考察する。供試体の形状, 寸法は, 図-6に示 すとおりであり, 従来の研究よりさらに実際的なモデル として母材(モルタル)にひび割れの発生を考慮した。各 材料の材料定数は表 -1 に示すように従来の実験結果 ${ }^{2)}$ より得られたものを用いた。供試体の種類は, 表-1に 示した 3 種類の樹脂材を 5 種類の組み合わせで 3 層塗布 したものとし，また層間せん断ばね定数は従来の実験結 
表-1 各材料定数

\begin{tabular}{c|c|c|c}
\hline & 弾性係数 $\left(\mathrm{kgf} / \mathrm{cm}^{2}\right)$ & ポアソン比 & 線膨張係数 $\left(\mu /{ }^{\circ} \mathrm{C}\right)$ \\
\hline モルタル & 237000 & 0.206 & 5.8 \\
\hline 樹脂材 $\mathrm{H}$ & 25100 & 0.419 & 95.1 \\
\hline 樹脂材 $\mathrm{M}$ & 9650 & 0.476 & 130.9 \\
\hline 樹脂材 $\mathrm{S}$ & 5900 & 0.401 & 104.9 \\
\hline
\end{tabular}

* 樹脂材の弾性係数およびポアソン比には, 温度および引張速度依存

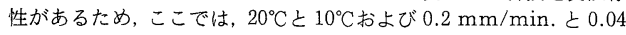
$\mathrm{mm} / \mathrm{min}$. の場合の実測値の平均値を用いた。

表-2 供試体の種類と層間せん断ばね定数

\begin{tabular}{c|c|c|c|c}
\hline 供試体 & 樹脂材の種類 & $k_{x 01}$ & $k_{x 12}$ & $k_{x 23}$ \\
\hline $\mathrm{HMH}$ & $\mathrm{H} / \mathrm{M} / \mathrm{H}$ & $1.0 \times 10^{5}$ & $2.5 \times 10^{4}$ & $1.0 \times 10^{8}$ \\
\hline $\mathrm{HMS}$ & $\mathrm{H} / \mathrm{M} / \mathrm{S}$ & $9.4 \times 10^{4}$ & $6.1 \times 10^{4}$ & $1.0 \times 10^{8}$ \\
\hline $\mathrm{MHM}$ & $\mathrm{M} / \mathrm{H} / \mathrm{M}$ & $3.2 \times 10^{4}$ & $1.0 \times 10^{6}$ & $1.0 \times 10^{8}$ \\
\hline $\mathrm{MSM}$ & $\mathrm{M} / \mathrm{S} / \mathrm{M}$ & $5.5 \times 10^{4}$ & $1.4 \times 10^{4}$ & $1.0 \times 10^{8}$ \\
\hline $\mathrm{SHM}$ & $\mathrm{S} / \mathrm{H} / \mathrm{M}$ & $4.0 \times 10^{3}$ & $4.7 \times 10^{5}$ & $1.0 \times 10^{8}$ \\
\hline
\end{tabular}

※ 樹脂材の種類の闌において各アルファベットは“1 層目の樹脂材 $/ 2$ 層目の樹脂材 $/ 3$ 層目の樹脂材”を表す。また, $k_{01}, k_{12}, k_{23}$ は 1 層目, 2 層目, 3 層目の層間せん断ばね定数を示し, 単位は $\mathrm{kgf} / \mathrm{cm}^{2}$ とする。

\section{表-3 応力拡大係数の解析条件}

\begin{tabular}{c|c|c}
\hline & 荷重条件 & 界面き裂場所 \\
\hline case 1 & 温度変化 & 樹脂材端部 \\
\hline case 2 & 温度変化 & スパン中央 \\
\hline case 3 & 曲げ載荷 & 樹脂材端部 \\
\hline case 4 & 曲げ載荷 & スパン中央 \\
\hline
\end{tabular}

表-4 各供試体の $K, G$

(a) 各供試体の $K_{1}\left(\right.$ 単位 $\mathrm{kgf} \cdot \mathrm{cm}^{-3 / 2}$ )

\begin{tabular}{l|l|l|l|l|c}
\hline & HMH & HMS & MHM & \multicolumn{1}{c}{ MSM } & \multicolumn{1}{c}{ SHM } \\
\hline case 1 & -2.307 & -1.835 & -1.889 & -1.131 & $-8.282 \mathrm{E}-01$ \\
\hline case 2 & $-6.348 \mathrm{E}-03$ & $-4.737 \mathrm{E}-03$ & $-4.516 \mathrm{E}-03$ & $-1.367 \mathrm{E}-03$ & $-1.375 \mathrm{E}-03$ \\
\hline case 3 & -2.178 & $-1.530 \mathrm{E}-01$ & $-1.654 \mathrm{E}-01$ & $-7.984 \mathrm{E}-02$ & $-5.575 \mathrm{E}-02$ \\
\hline case 4 & $2.779 \mathrm{E}-01$ & $3.359 \mathrm{E}-01$ & $2.659 \mathrm{E}-01$ & $1.603 \mathrm{E}-01$ & $5.071 \mathrm{E}-02$ \\
\hline
\end{tabular}

(b) 各供試体の $K_{2}\left(\right.$ 単位 $\mathrm{kgf} \cdot \mathrm{cm}^{-3 / 2}$ )

\begin{tabular}{l|l|l|l|l|l}
\hline & \multicolumn{1}{|c|}{ HMH } & \multicolumn{1}{c}{ HMS } & \multicolumn{1}{c}{ MHM } & \multicolumn{1}{c}{ MSM } & SHM \\
\hline case 1 & -4.984 & -4.131 & -3.211 & -2.092 & -1.075 \\
\hline case 2 & $6.117 \mathrm{E}-02$ & $3.483 \mathrm{E}-02$ & $3.116 \mathrm{E}-02$ & $1.104 \mathrm{E}-02$ & $-1.375 \mathrm{E}-03$ \\
\hline case 3 & $-5.016 \mathrm{E}-01$ & $-3.946 \mathrm{E}-01$ & $-3.078 \mathrm{E}-01$ & $-1.771 \mathrm{E}-01$ & $-1.236 \mathrm{E}-01$ \\
\hline case 4 & -2.581 & -2.352 & -1.698 & -1.154 & $-6.293 \mathrm{E}-01$ \\
\hline
\end{tabular}

（c）各供試体の $G$ (単位 $\mathrm{kgf} / \mathrm{cm}$ )

\begin{tabular}{c|c|c|c|c|c}
\hline & $\mathrm{HMH}$ & HMS & MHM & MSM & SHM \\
\hline case 1 & $1.829 \mathrm{E}-03$ & $1.239 \mathrm{E}-03$ & $2.870 \mathrm{E}-03$ & $1.169 \mathrm{E}-03$ & $1.331 \mathrm{E}-03$ \\
\hline case 2 & $2.284 \mathrm{E}-07$ & $7.493 \mathrm{E}-08$ & $2.051 \mathrm{E}-07$ & $2.562 \mathrm{E}-08$ & $1.043 \mathrm{E}-07$ \\
\hline case 3 & $1.798 \mathrm{E}-05$ & $1.086 \mathrm{E}-05$ & $2.526 \mathrm{E}-05$ & $7.806 \mathrm{E}-06$ & $1.328 \mathrm{E}-05$ \\
\hline case 4 & $4.084 \mathrm{E}-04$ & $3.424 \mathrm{E}-04$ & $6.113 \mathrm{E}-04$ & $2.806 \mathrm{E}-04$ & $2.882 \mathrm{E}-04$ \\
\hline
\end{tabular}

果 ${ }^{2)}$ より同定されたものを用いた。本研究で用いた供試 体の種類と層間せん断ばね定数をまとめて表-2 に示 す。

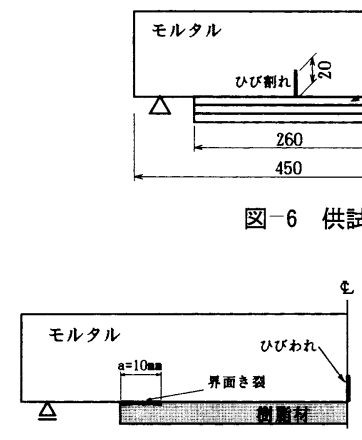

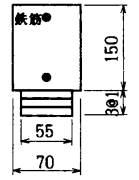

$\stackrel{\mathrm{70}}{\longrightarrow}$
-6 供試体 (単位 $\mathrm{mm}$ ) (a ) 樹脂材端部

図-7 界面き裂位置
界面き裂は長さ $1 \mathrm{~cm}$ とし, 図-7 (a)，(b) のように 特に大きな応力集中が起こると考えられる樹脂材端部に ある場合と，スパン中央（母材のひび割れ近傍）にある 場合の 2 通りを考え, 荷重条件は, 温度変化を $10^{\circ} \mathrm{C}$ 受 ける場合と, 道路橋示方書の設計荷重に相当する荷重 $600 \mathrm{kgf}$ の曲げ載荷 (スパン $l=40 \mathrm{~cm}$ ) を受ける場合を 考えた。荷重条件と界面き裂位置の組み合わせとして表 -3 に示す 4 case を考え, 破壊力学パラメータである応 力拡大係数 $K_{1}, K_{2}$ およびエネルギー開放率 $G$ を外挿 法を用いて求めた。得られた結果をまとめて表 -4 (a) ( c) に示す。

表-4 (a) より， $K_{1}$ は case 4 を除き負の値となって おり, 界面の剶離と反対方向の応力拡大係数を示してい ることになり, 界面の剝離方向の破壊, すなわち, $K_{1}$ は材料選定において考慮する必要がないと考えてよい。

次に，表-4 (b) より, $K_{2}$ は case 2 を除き 3 つの case で負の値となっている。この場合の符号について は, 単に界面のせん断方向破壊の方向の相違を示すもの であり, $K_{2}$ の評価はこれらの絶対值を用いる必要がある と考えられる。したがって，各 caseにおける $K_{2}$ を絶 対值で比較すると, case 2, 3 については他の 2 つの case に比べてその值は小さく材料選定上の組み合わせ として考慮する必要はないと考えられる。case 1 の $K_{2}$ の絶刘值が各供試体の中で最も大きくなっており, case 4 の $K_{2}$ の絶対值は case 1 の約 $1 / 2$ となっている。ま た, case 2, case 4 とも各供試体間での傾向はよく似た ものとなっている。供試体 MHM と供試体 SHM を比 較すると, 1 層目の弾性係数が小さいほど $K_{2}$ の值は小 さくなっている。供試体 MHM と供試体 MSM を比較 すると, 2 層目の弾性係数が小さいほど $K_{2}$ の值は小さ くなり, また, 供試体 $\mathrm{HMH}$ と供試体 HMS を比較す 
ると 3 層目の弾性係数が小さいほど $K_{2}$ の值は小さくな るのがわかる。つまり, 塗布する樹脂材の剛性が小さい ほど $K_{2}$ の值は小さくなり, き裂の進展, 界面破壊が生 じにくいと考えられる。

一方, 表-4 (c) のエネルギー開放率 $G$ については, 式 (10) からも明らかなように応力拡大係数の符号の相 違が無くなり，混合モードの破壊に関するエネルギー開 放率を示す。したがって, 剥離方向の $K_{1}$ も同時に考慮 していることになり，せん断方向破壊のみに着目した考 察はできないと考えられる。

以上のことから, 本研究における材料設計に関しては 応力搪大係数 $K_{2}$ を用いた材料選定指標を考案すること にする。また材料設計をする際, 界面き裂を考慮すべき 応力集中部として問題となる case としては, 先に考察 した 4 つの case の内 case 1 および case 4 の場合であ ると考えられ, 他の case については表-4 の応力拡大 係数から考えて界面き裂の影響は小さく, 応力集中も小 さいので材料選定上は考慮する必要はないと考えられ る。したがって, 以下本研究を進めるうえで温度変化を 受ける場合は樹脂材端部の界面き裂先端付近の応力集 中, 曲げを受ける場合はモルタルのひび割れ近傍の界面 き裂先端での応力集中に着目することとする。

\section{4 応力拡大係数のパラメータ解析}

温度変化を受ける場合の樹脂材端部の界面き裂 (case I), 曲げを受ける場合のモルタル中のひび割れ近傍の界 面き裂 (case II) の応力集中を対象として, 応力拡大係 数 $K_{2}$ の支配パラメータとして考えられる各層樹脂材の 弾性係数を用いたパラメー夕解析を行った。このとき解 析に用いた層間せん断ばね定数は, 式 (11), (12) に示 す従来の研究 ${ }^{2)}$ より得られた各層の弾性係数によりモデ ル化されたものを用いた。

$$
\begin{gathered}
k_{01}=7.109 E_{1}-1.352 E_{2}-3.978 E_{3}+35455.1 \\
\log \left(k_{12}\right)= \\
-1.600 \times 10^{-4} E_{1}+9.740 \times 10^{-5} E_{2} \\
-1.960 \times 10^{-4} E_{3}+4.238
\end{gathered}
$$

ここで, $k_{01}, k_{12}$ はそれぞれ 1 層目, 2 層目の層間せ ん断ばね定数とし, 3 層目層間せん断ばね定数は, 樹脂 材の弾性係数に関係なく $1.0 \times 10^{8} \mathrm{kgf} / \mathrm{cm}^{2}$ とした。

各層樹脂材の弾性係数を 5000 20000 kgf/ $\mathrm{cm}^{2}$ まで $5000 \mathrm{kgf} / \mathrm{cm}^{2}$ ピッチで変化させ, 応力拡大係数 $K_{2}$ の 変化を調べた。図-8に 2,3 層目の弾性係数を一定とし, 1 層目弾性係数 $E_{1}$ を変化させたときの $K_{2}$ の変化, 1,3 層目の弾性係数を一定とし, 2 層目弾性係数 $E_{2}$ を変化 させたときの $K_{2}$ の変化, 1,2 層目の弾性係数を一定と し, 3 層目弾性係数 $E_{3}$ を変化させたときの $K_{2}$ の変化 をそれぞれ示した。

これより，以下のことが明らかとなる。

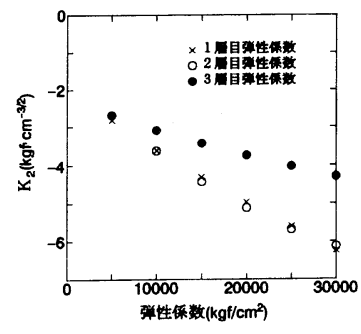

（a）温度変化を受ける場合 (case I )

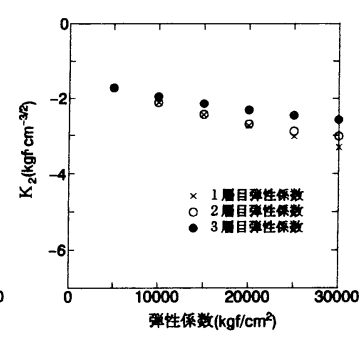

（ｂ）曲げを受ける場合 (case II)
図-8 $\quad K_{2}$ に対する各層弾性係数の感度

(1) 1 層目の弾性係数の感度は case I, II とも 1 層目 弾性係数が大きいほど $K_{2}$ の絶対值は大きくなってい る。また, case I, II を比較すると case I のほうが 1 層 目弾性係数の感度が大きい。

(2) 2 層目の弾性係数の感度は 1 層目の弾性係数之同様 の傾向を示しており, case I, II とも 2 層目の弾性係数 が大きいほど $K_{2}$ の絶対值は大きくなっている。case I のほうが case II より 2 層目の弾性係数の感度が大き い。また, case I については, 1, 2 層目の弾性係数の感 度はほぼ等しい結果となっており, case IIについては, 若干 1 層目の感度が大きくなっているが, 1,2 層目の弾 性係数の感度は case I と同様にほぼ等しい結果となっ ている。

(3) 1, 2 層目の弾性係数の感度と比較すると, 3 層目の 感度は case I, II とも小さくなっている。各 case とも 傾向は 1,2 層目の弾性係数とほぼ同様であり，3 層目の 弾性係数が大きいほど $K_{2}$ の絶対值は大きくなってい る。また, case I の 3 層目の感度のほうが case II の感 度より大きい。

以上のことをまとめると, case I, case II とも $K_{2}$ に 対する各層樹脂材弾性係数の感度は 1 層目, 2 層目はほ とんど違いがないようであるが, $E_{1}>E_{2}>E_{3}$ の傾向が 見られる。また, caseごとの比較では case I > case II と なっている。

3. 指標 $A \tau$ を用いた積層化樹脂材界面 の力学的挙動の評価

従来の研究2)では実験供試体で得られた層間せん断応 力分布および層間温度応力分布からその応力集中部に着 目し, 応力分布之樹脂材端部からの距離が囲む面積を母 材の平均せん断応力 $\left(\tau_{\text {mean }}=P / 2 A, P\right.$ : 荷重, $A$ : 母 材断面積), 熱応力 $\left(\sigma_{0}=E_{0} \alpha_{0} \Delta t, E_{0}\right.$ : 母材弾性係数, $\alpha_{0}$ : 母材線膨張係数, $\Delta t$ : 温度変化量) およびスパン 長 (l) で無次元化したものを界面の破壊に寄与する指標 $A \tau$ とし ${ }^{2)}$, 界面ではがれないという力学的要求性能に 対する積層化樹脂材の材料選定手法の検討を行った。そ 
して, 指標 $A \tau$ の值が小さいほど界面ではがれにくい ものと考え，指標 $A \tau$ をできるだけ小さくするような 組み合わせを考えるという材料設計手法を提案した。

本研究では, 種々の供試体を用いた界面の静的破壊試 験を行うことにより解析を併用して指標 $A \tau$ の限界值 $A \tau_{c}$ を求め, 塗布する樹脂材の弾性係数と $A \tau_{c}$ の関係 を定性的に評価し，A $\tau_{c}$ を用いた材料選定指標を提案 することを考えた。

\section{1 静的破壊試験の概要}

界面の接着強度特性を調べるため界面破壊試験を行 い, また樹脂材およびモルタルの弾性係数を得るために 引張り試験および圧縮試験を行った。以下にそれぞれの 供試体および実験の概要を示す。

(1) 引張り試験

引張り試験供試体は樹脂材が粘弾性体であること, 弾 性係数がかなり小さな領域にあることを考慮し, 引張り 試験を行ったときに供試体のつかみ部分で破壊しないよ うにひずみの測定部分の幅に比べて十分大きなつかみ部 分の幅を持つ供試体を用意した。図一のに引張り試験供 試体の形状および寸法を示す。この供試体は, JIS K 7113 における 2 号型試験片を 1.6 倍で相似的に拡大し たものである。引張り試験供試体には, 静的破壊試験で 使用した弾性係数の異なるエポキシ樹脂材 $\mathrm{H}, \mathrm{M}, \mathrm{S}$ の 3 種類を用いた。

本実験では, ひずみゲージによるひずみ测定を行っ た。ひずみゲージ貼り付け位置は図-9に示したとおり である。引張り速度は, 静的破壊試験における引張り速 度と同じ速度 $(0.5 \mathrm{~mm} / \mathrm{min}$. ) で実験を行った。ま た, 試験は, $20^{\circ} \mathrm{C}$ 恒温状態で行った。

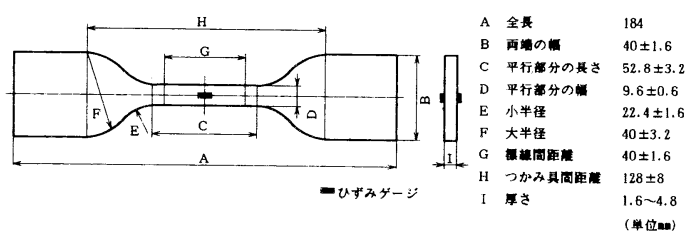

図一9 引張り試験供試体

\section{（2）圧縮試験}

圧縮試験供試体は早強セメントと豊浦標準砂を用いた モルタルで, 配合は $C / S=0.45, W / C=0.75$ とした。

モルタル供試体の圧縮試験はコンクリートの圧縮試験 に準じた方法で行った。試験は, 静的破壊試験と同じ材 齢 31 日で行った。

\section{（3）界面での静的破壊試験}

界面での破壊試験供試体の形状および寸法を図一10に 示す。母材にはモルタルを使用し, 表-1に示した弾性 係数の異なるエポキシ樹脂材を 1 層塗布した供試体を用 いた。また, 塗布する樹脂材の引張り部分の形状は, 引
張り試験供試体と同様のものを用いた。塗布する樹脂材 厚 $t$ は $3 \mathrm{~mm}$ および $5 \mathrm{~mm}$ とし, 樹脂材厚を変化させ ることにより層間せん断応力の集中領域に変化をもた せ, 同じ荷重条件での塗布厚の違いによる応力集中特性 の違いを評価した。表 -5 に供試体の種類, 個数などを 示す。

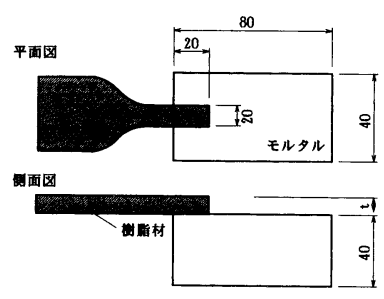

図-10 破壊試験供試体（単位 $\mathrm{mm}$ )

\begin{tabular}{c|c|c}
\multicolumn{2}{c}{ 表 -5 供試体の種類・個数 } \\
\hline 樹脂材の種類 & 樹脂材彸布厚 & 供試体数 \\
\hline $\mathrm{H}$ & $3 \mathrm{~mm}$ & 2 体 \\
\hline $\mathrm{H}$ & $5 \mathrm{~mm}$ & 2 体 \\
\hline $\mathrm{M}$ & $3 \mathrm{~mm}$ & 2 体 \\
\hline $\mathrm{M}$ & $5 \mathrm{~mm}$ & 2 体 \\
\hline $\mathrm{S}$ & $3 \mathrm{~mm}$ & 2 体 \\
\hline $\mathrm{S}$ & $5 \mathrm{~mm}$ & 2 体 \\
\hline
\end{tabular}

界面での破壊試験供試体のひずみゲージ貼り付け位置 を図一11に示す。本来は界面上のひずみを測定するのが 理想的であるが, それが困難であるため樹脂材表層のひ ずみを測定することとした。実験は $20^{\circ} \mathrm{C}$ 恒温状態で行 い, 引張り速度は $0.5 \mathrm{~mm} / \mathrm{min}$. とした。界面で破壊 を起こさせるように図-12 のように樹脂材のつかみ部を 引張るときに界面に偏心によるモーメントが作用しない ようにモルタル母材を完全に固定できる治具を用い, 樹 脂材塗布厚に応じてアダプタを取り替え界面が引張りの 中心となるようにした。

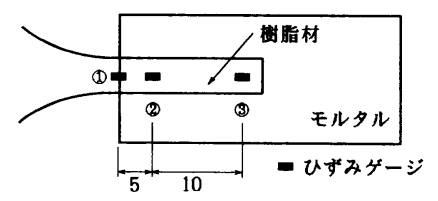

図-11 ひずみゲージ貼り付け位置 (単位 $\mathrm{mm}$ )

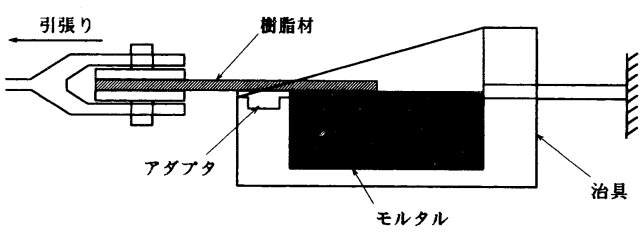

図-12 実験概要図 


\section{2 実験結果とその考察}

(1) 引張り試験

界面の静的破壊試験の樹脂材引張り速度と同じ速度で 樹脂材の引張り試験を行い, 樹脂材の弾性係数を求め た。得られた弾性係数を表-6にまとめて示す。

JIS に規定されているプラスチックの引張り試験速度 は通常 $1.0 \mathrm{~mm} / \mathrm{min}$. であるが, 本研究で対象とする 樹脂材の引張り速度は温度変化などを考慮すると極低速 であると考えられ, 通常の速度から求めた樹脂材の弾性 係数を材料のデータとして用いるのは適当でないと考元 られる。したがって, 本研究では試験機の精度が保証で きる範囲でできるだけ低速で試験を行った。

表-6 樹脂材引張り試験結果

\begin{tabular}{c|c|c}
\hline 供試体 & $\begin{array}{c}\text { 弾 性 係 数 } \\
\left(\mathrm{kgf} / \mathrm{cm}^{2}\right)\end{array}$ & $\begin{array}{c}\text { 平 均 } \\
\left(\mathrm{kgf} / \mathrm{cm}^{2}\right)\end{array}$ \\
\hline H 1 & 12130 & 11810 \\
\hline H 2 & 11490 & \multirow{2}{*}{9040} \\
\hline M 1 & 9100 & \\
\hline M 2 & 8980 & 6900 \\
\hline S 1 & 7010 & \\
\hline S 2 & 6790 & \\
\hline
\end{tabular}

\section{（2）圧縮試験}

界面の静的破壊試験供試体に用いたモルタルの材齢と 同時期に圧縮試験を行い, モルタルの弾性係数を求め た。その結果, モルタルの弾性係数の平均值は $2.41 \times$

\section{表 -7 測定ひずみの平均值}

\begin{tabular}{|c|c|c|c|c|c|c|c|c|c|c|}
\hline \multirow{2}{*}{\multicolumn{2}{|c|}{ 供試体 }} & \multicolumn{9}{|c|}{ 測定ひずみの平均値 $(\mu)$} \\
\hline & & 0.0 & 12.5 & 25.0 & 37.5 & 50.0 & 62.5 & 75.0 & 87.5 & 100.0 \\
\hline \multirow{3}{*}{$\mathrm{H} 3 \mathrm{~mm}$} & 测点(1) & 0 & 1253 & 2612 & 4023 & 5549 & 7271 & 9440 & 12904 & \\
\hline & 测点(2) & 0 & 559 & 1157 & 1792 & 2530 & 3530 & 5196 & 8360 & \\
\hline & 测点(3) & 0 & 78 & 162 & 244 & 359 & 513 & 737 & 839 & \\
\hline \multirow{3}{*}{$\mathrm{H} 5 \mathrm{~mm}$} & 測点(1) & 0 & 1138 & 2716 & 3622 & 4756 & 6170 & 7142 & 8964 & 10934 \\
\hline & 測点(2) & 0 & 548 & 1240 & 1630 & 2159 & 2755 & 3271 & 4079 & 5185 \\
\hline & 測点(3) & 0 & 94 & 223 & 267 & 392 & 500 & 609 & 869 & 1137 \\
\hline \multirow{3}{*}{$\mathrm{M} 3 \mathrm{~mm}$} & 測点(1) & 0 & 2751 & 5047 & 7093 & 9185 & 11982 & 14668 & 18250 & \\
\hline & 測点(2) & 0 & 522 & 1041 & 1573 & 2160 & 3458 & 6255 & 8919 & \\
\hline & 測点(3) & 0 & 48 & 100 & 154 & 211 & 331 & 629 & 903 & \\
\hline \multirow{3}{*}{ M $5 \mathrm{~mm}$} & 測点(1) & 0 & 1690 & 3278 & 4942 & 6449 & 7960 & 9453 & 10998 & \\
\hline & 測点(2) & 0 & 944 & 1890 & 2910 & 3877 & 4880 & 5912 & 7072 & \\
\hline & 測点(3) & 0 & 121 & 238 & 364 & 483 & 602 & 728 & 877 & \\
\hline \multirow{3}{*}{$\mathrm{S} 3 \mathrm{~mm}$} & 測点(1) & 0 & 2113 & 4341 & 6682 & 9835 & 14074 & 19412 & & \\
\hline & 測点(2) & 0 & 839 & 1723 & 2674 & 3908 & 6170 & 10663 & & \\
\hline & 測点(3) & 0 & $29 !$ & 62 & 97 & 154 & 268 & 454 & & \\
\hline \multirow{3}{*}{$\mathrm{S} 5 \mathrm{~mm}$} & 測点(1) & 0 & 1798 & 3581 & 5350 & 7126 & 8914 & 10836 & 12944 & \\
\hline & 測点(2) & 0 & 1023 & 2048 & 3075 & 4153 & 5304 & 6943 & 9288 & \\
\hline & 測点(3) & 0 & 116 & 234 & 352 & 471 & 595 & 757 & 985 & \\
\hline
\end{tabular}

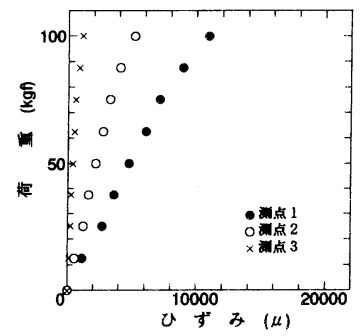

(a) $\mathrm{H} 5 \mathrm{~mm}$ 供試体

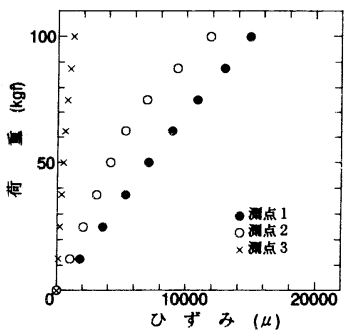

(b) $\mathrm{S} 5 \mathrm{~mm}$ 供試体
図-13 荷重-ひずみ関係

$10^{5} \mathrm{kgf} / \mathrm{cm}^{2}$ となった。

(3) 静的破壊試験

静的破壊試験における破壊形式は, 各供試体ともモル タルの極表層での界面破壊であった。各供試体の静的破 壊試験で測定されたひずみの平均值を表-7に示す。ま た, 図-13 (a), (b)に, 一例として S $5 \mathrm{~mm}$ および $\mathrm{H}$ $5 \mathrm{~mm}$ 塗布供試体の荷重-ひずみ関係を示す。図-13よ り各供試体とも測定ひずみの值に差異が見られるが，荷 重一ひずみ関係はほぼ同様の傾向を示しており, 実験は ほぼ弾性域で行われたと考えられ，解析に本研究で用い ている 2 次元弾性 FEM 解析を適用して問題はないと考 えられる。ひずみの值は各供試体ともモルタル端部（測 点(1)）で大きな值を示しており，その部分で形状の変化 による応力集中が生じていると考えられる。

次に, 各供試体の破壊荷重を表-8に示す。破壊荷重 は樹脂材の弾性係数が大きいほど大きいという傾向があ り, また, 樹脂材塗布厚が大きいほど若干ではあるが破 壊荷重が大きくなるという傾向があることがわかる。

\section{表-8 各供試体の破壊荷重}

\begin{tabular}{c|c|c|c}
\hline \multirow{2}{*}{ 厚さ } & \multicolumn{3}{|c}{ 破壊荷重 $(\mathrm{kgf})$} \\
\hline & $\mathrm{H}$ 供試体 & $\mathrm{M}$ 供試体 & $\mathrm{S}$ 供試体 \\
\hline $3 \mathrm{~mm}-1$ & 100.251 & 96.840 & 95.968 \\
\hline $3 \mathrm{~mm}-2$ & 102.647 & 100.200 & 83.670 \\
\hline 平 均 & 101.449 & 98.520 & 89.819 \\
\hline $5 \mathrm{~mm}-1$ & 110.000 & 97.250 & 91.750 \\
\hline $5 \mathrm{~mm}-2$ & 112.290 & 102.210 & 95.000 \\
\hline 平 均 & 111.145 & 99.730 & 93.375 \\
\hline 全平均 & 105.328 & 99.004 & 91.597 \\
\hline
\end{tabular}

\section{3 実験から得られる $A \tau$ の限界値 $A \tau_{c}$}

実験に基づいて界面における力学的挙動を評価する場 合, 未知のパラメータである層間せん断ばね定数を求め る必要がある。この值を求めるために, 数值解析におい て層間せん断ばね定数を仮定して求めた樹脂材のひずみ 分布と実験で測定されたひずみ分布の形状が一致するよ 
うに逐次線形計画法 (SLP 法 $)^{2), 12)}$ を用いて同定し た。同定結果を表-9にまとめて示す。同定された層間 せん断ばね定数は, 樹脂材の塗布厚にはあまり関係な く, 樹脂材の弾性係数之相関か認められ, 樹脂材の弾性 係数が大きいほど層間せん断ばね定数は大きくなってい る。

\begin{tabular}{|c|c|}
\hline 表-9 & $\begin{array}{l}\text { ん断ばね定数の } \\
\text { 果 }\end{array}$ \\
\hline 供試体 & $k_{x}\left(\mathrm{kgf} / \mathrm{cm}^{2}\right)$ \\
\hline $\mathrm{H} 3 \mathrm{~mm}$ & $5.51 \times 10^{4}$ \\
\hline H $5 \mathrm{~mm}$ & $5.73 \times 10^{4}$ \\
\hline M $3 \mathrm{~mm}$ & $4.94 \times 10^{4}$ \\
\hline M $5 \mathrm{~mm}$ & $5.11 \times 10^{4}$ \\
\hline $\mathrm{S} 3 \mathrm{~mm}$ & $4.47 \times 10^{4}$ \\
\hline $\mathrm{S} 5 \mathrm{~mm}$ & $4.39 \times 10^{4}$ \\
\hline
\end{tabular}

前述のように各供試体は破壊寸前まで弾性挙動を示し たと考えられるため, 同定された層間せん断ばね定数を 用いて破壊直前の層間せん断応力分布を 2 次元 FEM 解 析により求めた。各供試体の破壊直前の層間せん断応力 分布を図-14 (a) ( c c)に示す。解析では, 供試体寸 法, 破壊荷重は同一供試体での平均值を用いた。 $3 \mathrm{~mm}$ 登布供試体の層間せん断応力分布は, 各供試体ともほぼ 同様な分布となっており, 樹脂材の弾性係数による応力 分布の相違はほとんど見られない。 $5 \mathrm{~mm}$ 塗布供試体 についても同様のことがいえ, 樹脂材の弾性係数の違い による応力分布の相違は見られない。また, 樹脂材の塗 布厚の違いによる影響としては, 塗布厚が大きいと層間 せん断応力分布の応力勾配が若干小さくなっていること が挙げられるがよく似た分布形状になっていることがわ かる。

図-14に示した層間せん断応力分布において，その応 力集中部の最大応力值は理論上無限大になると考えられ る。そのため界面での破壊を考える場合, 解析で得られ た応力の最大值の大小が破壊を支配するとはいえない。 したがって, 応力集中部においてその応力の絶対值と応

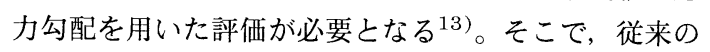
研究 ${ }^{2)}$ では層間せん断応力分布からその応力集中部に着 目し, 応力分布と樹脂材端部からの距離が囲む面積を界 面の破壊に寄与する指標 $(A \tau)$ とした。この指標を用 いれば, 先に述べた応力の絶対值とその勾配の両方を考 慮することができ, この指標を小さくする材料選択を行 うことにより, 応力集中部のエネルギーを小さくするこ とになり, 破壊に対する指標になり得ると考えた。従来 の研究では, 指標 $A \tau$ の無次元化パラメー夕（基準 量) として, 樹脂材端部からの距離に対してはスパン $(l)$, 層間せん断応力に対しては母材の平均せん断応力 $\left(\tau_{\text {mean }}=P / 2 A, P\right.$ : 荷重, $A:$ 母材断面積), 層間温度

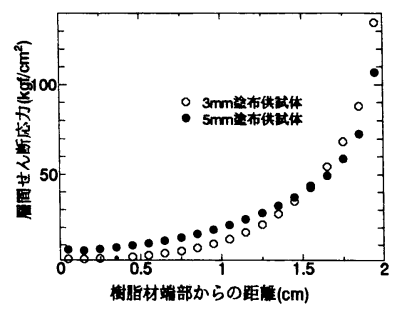

(a) $\mathrm{H}$ 塗布供試体

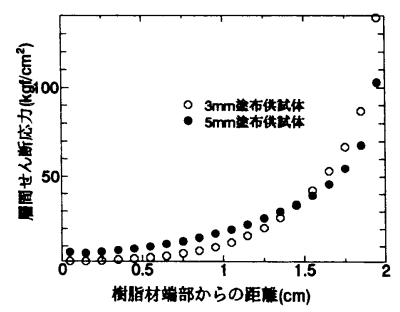

(b) $\mathrm{M}$ 塗布供試体

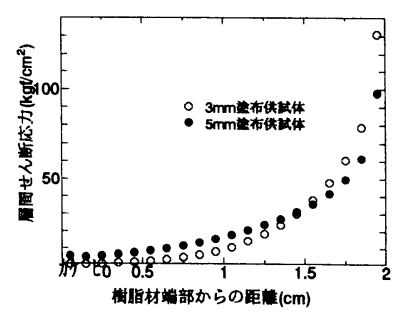

(c) $\mathrm{S}$ 塗布供試体

図-14 層間せん断応力分布

応力に対しては母材の熱応力（熱応力 $\left(\sigma_{0}=E_{0} \alpha_{0} \Delta t, E_{0}\right.$ : 母材弾性係数, $\alpha_{0}$ : 母材線膨張係数, $\Delta t$ : 温度変化 量）を考えた。しかし, 無次元化するパラメー夕に関し てはその根拠もなく指標にスパンが要因として入ってく るのかどうかも未検討である。そこで, 各供試体につい て図-14 の層間せん断応力分布之樹脂材端部からの距離 が囲む面積を無次元化せずにそのまま求め,これを $A \tau$ の破壊に対する限界值 $A \tau_{c}$ として表-10にまとめて示 した。実際には, モルタルの強度が破壊荷重あるいは $A \tau_{c}$ に影響を及ぼすことが考えられるが, 本研究で は, 塗布する樹脂材を選択することを考えており樹脂材 を対象とした定性的な評価を行うものとする。

表-10 より, $\mathrm{H}$ 塗布供試体については, 塗布厚の違い によるばらつきと考えられるものがみられるものの, 他 の供試体については塗布厚の違いによる $A \tau_{c}$ の違いは あまり見られない。したがって, 界面破壊に対するパラ メータとして樹脂材の塗布厚はあまり重要でないと考え られる。しかし, 樹脂材の弾性係数の違いに着目すると 弾性係数が大きいほど $A \tau_{c}$ の值は大きくなっており, $A \tau_{c}$ と樹脂材弾性係数の間に相関が認められる。そこ 


\begin{tabular}{|c|c|}
\hline 供 試 体 & $A \tau_{\mathrm{c}}(\mathrm{kgf} / \mathrm{cm})$ \\
\hline $\mathrm{H} 3 \mathrm{~mm}$ & 55.6 \\
\hline H $5 \mathrm{~mm}$ & 59.2 \\
\hline 平 均 & 57.4 \\
\hline M $3 \mathrm{~mm}$ & 54.2 \\
\hline M $5 \mathrm{~mm}$ & 54.8 \\
\hline 平 均 & 54.5 \\
\hline $\mathrm{S} 3 \mathrm{~mm}$ & 49.2 \\
\hline $\mathrm{S} 5 \mathrm{~mm}$ & 50.2 \\
\hline 平 均 & 49.7 \\
\hline
\end{tabular}

で, $A \tau_{c}$ を樹脂材弾性係数 $E$ でモデル化した。以下に その結果を示す。

$$
A \tau_{c}=1.543 \times 10^{-3} E+39.59
$$

(相関係数 $r=0.9543$ )

一般に, 樹脂材の弾性係数が大きいほど接着強度も大き いと考えられており，本実験結果はそれを証明している と考えられる。

\section{$3.4 A \tau_{c}$ を用いた力学的材料選定指標の検討}

上述の $A \tau$ の界面破壊に対する限界値 $A \tau_{c}$ は, 界面 の静的破壊に関する限界值である。 $A \tau_{\mathrm{c}}$ を破壊の限界 値とするなら塗布する樹脂材の厚みに関係なく $A \tau_{c}$ の 值は一定になるはずであり，式 (13) に基づく材料選定 を考えればよく, 界面の静的破壊に関しては指標 $A \tau$ は有効之なると考えられる。しかし, 静的荷重の観点か ら考えると, 材料選定を行う際, 本研究で行った実験の ように積層化樹脂材界面に静的に大きな荷重が作用する ことは，終局限界状態等を対象とした補強を考えるなら 考えられるが, 通常の補修を対象とする場合はまず考え られない。温度変化 $10^{\circ} \mathrm{C}$, または道路橋示方書に基づ

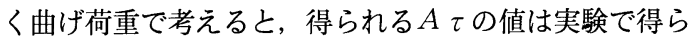
れた $A \tau_{c}$ の $1 / 10$ 程度である。したがって, $\alpha=A$ て/A $\tau_{c}$ を考えると常に $\alpha<1.0$ となり, どのような弾性係数の 樹脂材を組み合わせて塗布しても界面破壊は起こらない という結果になる。しかし，実際の補修現場では，界面 において破壊が起こっており,コンクリート部材の劣 化, または, 力学的観点から考えられる破壊としては疲 労による破壊が挙げられる。実際に, もし応力集中部で 界面破壊が生じ，一部樹脂材が剝がれたとしてもその界 面破壊が樹脂材の塗布面全体に及ぼす影響はおそらく小 さく,すぐに樹脂材の塗り替えが行われることはないで あろう。問題となるのは界面で一部損傷が生じた場合に その後の積層化樹脂材界面でのき裂の進行であると考え られる。この場合の界面における力学的挙動を解明する ためには，本来なら静的試験で得られた破壊荷重の何\% かの荷重条件で度労試験を行い, $\mathrm{S}-\mathrm{N}$ 曲線と同様な $A \tau$ と荷重の繰返し回数 $N$ の関係を求め $A \tau$ の疲労に対す
る有効性を検討する必要がある。本研究でも静的破壊試 験と同一供試体を用いて界面の疲労試験を試みたが, 樹 脂材自身の破断等の現象が先行して起こり, 良好な結果 が得られなかった。したがって,ここでは $A \tau$ の疲労 に対する有効性を評価することは不可能である。

したがって, 本研究では, 実際の界面破壊現象を考慮 し，コンクリートの劣化，または疲労に対する $A \tau$ の 限界值として実験で得られた $A \tau_{c}$ の $15 \%$ を破壊に関 する限界値として想定し，材料選定に用いることとし た。すなわち, 式 (13) を改めて $A \tau_{c}$ を次式のように設 定する。

$$
A \tau_{c}=2.315 \times 10^{-4} E+5.939
$$

$A \tau_{c}$ の值の設定に関しては，実際に実験等によりさ らに検討を加えていく必要があるが, 材料選定の際には 何らかの形で選定指標の限界值を設定する必要があり, 本研究では上記のように設定した。

そこで, 従来の研究で考案された指標 $A \tau$ に基づく 材料選定指標として指標 $\alpha=A \tau / A \tau_{c}$ を考え， $\alpha<1.0$ となる組み合わせは界面で破壊しないものと仮定した。

指標 $\alpha$ を従来の研究 ${ }^{2}$ で用いられた供試体に適用し た。供試体寸法, 材料定数, 供試体の種類は図 -6 およ び表-1, 表-2 に示したもの之同様のものを用い, 荷重 条件は温度変化を受ける場合, 曲げを受ける場合の両者 を考え，界面き裂はないものと考えた。まず，図一15， 図-16 に供試体 HMH および MSM の層間温度応力分

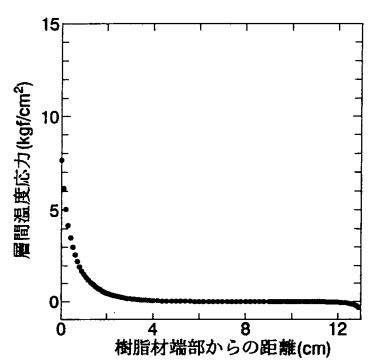

(a) $\mathrm{HMH}$ 塗布供試体

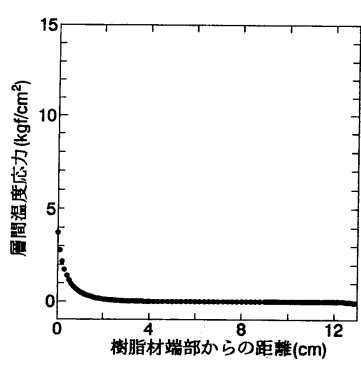

(b) MSM 塗布供試体
図-15 層間温度応力分布

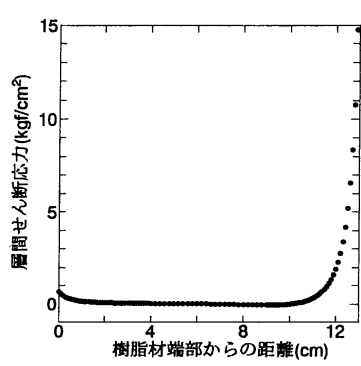

(a) $\mathrm{HMH}$ 塗布供試体

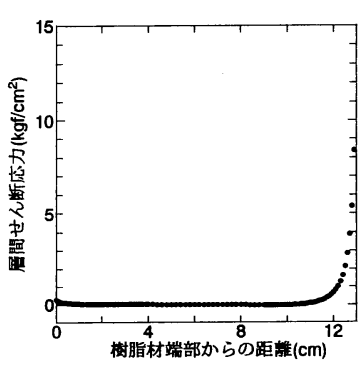

(b) MSM 塗布供試体
図-16 層間せん断応力分布 
布および層間せん断応力分布を一例として示す。これよ り，モルタルに導入したひび割れの影響は曲げを受ける 場合に顕著に現れ，また，樹脂材端部の形状の影響は温 度変化を受ける場合に顕著に現れている。したがって， 温度変化を受ける場合は樹脂材端部の応力集中領域に, 曲げを受ける場合はモルタルのひび割れ近傍の応力集中 領域にそれぞれ着目するものとする。また両図より，各 供試体とも応力集中幅は, 樹脂材端部より約 $3 \mathrm{~cm}$, ひ び割れ位置より約 $3 \mathrm{~cm}$ となっており，ほぼ等しいこと がわかる。

各供試体での指標 $\alpha$ の算定結果を表-11 に示す。ここ で, 温度変化を受ける場合を $\alpha_{T}$, 曲げを受ける場合を $\alpha_{L}$ とし，両者を区別することとした。これより，力学 的要求性能として界面ではがれないことを考えると温度 変化を受ける場合は, 供試体 MSM が最適な組み合わ せであると考えられ，一方，曲げを受ける場合は，供試 体 SHM が有効な組み合わせであると考えられる。すな わち, 温度変化を受ける場合は, 供試体 SHM と供試体 MHM を比較すると 1 層目弾性係数は小さいほうがよ く, 供試体 MHM と供試体 MSM を比較すると 2 層目 弾性係数が小さいほうがよく, 供試体 HMS と供試体 $\mathrm{HMH}$ を比較すると 3 層目弾性係数も小さいほうがよい ことがわかる。また，曲げを受ける場合も各層の樹脂材 の弾性係数の比較では，温度変化を受ける場合之同様の ことがいえる。温度変化，曲げを受ける場合のそれぞれ を比較すると曲げを受ける場合のほうが指標 $\alpha$ の値は大 きくなり, 指標 $\alpha<1.0$ の組み合わせを考えると, 温度変 化を受ける場合は全供試体について界面でのはがれはな いと考えられ，曲げを受ける場合は供試体 $\mathrm{HMH}$, 供試体 HMS は適当でなく, 供試体 MHM, 供試体 MSM, 供試体 SHM の組み合わせが界面ではがれないという力学的要 求性能に対して有効な組み合わせであると考えられる。

表-11 各供試体の指標 $\boldsymbol{\alpha}$

\begin{tabular}{c|c|c|c|c|c}
\hline 供試体 & HMH & HMS & MHM & MSM & SHM \\
\hline 指標 $\alpha_{T}$ & 0.4473 & 0.2887 & 0.5067 & 0.2601 & 0.4027 \\
\hline 指標 $\alpha_{L}$ & 1.2201 & 1.0667 & 0.9333 & 0.8067 & 0.3307 \\
\hline
\end{tabular}

さらに，応力拡大係数の解析を行ったときと同様に界 面にき裂が生じた場合について解析を行い, 層間温度応 力および層間せん断応力を求め, 指標 $\alpha$ を各供試体で比 較した。表-12 にそれぞれの場合の指標 $\alpha$ を示す。ここ で, 界面き裂がある場合の指標 $\alpha$ を指標 $\alpha^{\prime}$ とし, 界面 き裂がない場合と区別した。これによると温度変化を受 ける場合は, 界面き裂がない場合と比べて指標 $\alpha^{\prime}$ の值 は若干小さくなるがほぼ同様の結果となり, 界面き裂の 影響はほとんどないと考えられる。一方，曲げを受ける
場合は, 界面き裂がない場合の $1 / 3 \sim 1 / 4$ 程度の值と なっており, 界面き裂により応力集中部のエネルギーが 解放されたことと, き裂先端位置にモルタルのひび割れ による形状の変化の影響が小さくなったためであると考 えられる。各供試体を比較したときの全体的な傾向は, 界面き裂がない場合とほぼ同様の傾向を示している。

表-12 各供試体の指標 $\boldsymbol{\alpha}^{\prime}$

\begin{tabular}{c|c|c|c|c|c}
\hline 供試体 & $\mathrm{HMH}$ & $\mathrm{HMS}$ & $\mathrm{MHM}$ & $\mathrm{MSM}$ & $\mathrm{SHM}$ \\
\hline 指標 $\alpha_{T^{\prime}}$ & 0.4467 & 0.2853 & 0.5053 & 0.2573 & 0.4013 \\
\hline 指標 $\alpha_{L^{\prime}}$ & 0.4067 & 0.3027 & 0.3993 & 0.2133 & 0.1933 \\
\hline
\end{tabular}

したがって指標 $\alpha$ を考える場合, 温度变化を受ける場 合, 曲げを受ける場合とも指標 $\alpha>$ 指標 $\alpha^{\prime}$, 指標 $\alpha^{\prime}$ $<1.0$ となり, 各供試体間での比較でも指標 $\alpha$ および $\alpha^{\prime}$ はほぼ同様の結果となることから，指標 $\alpha$ を考える場合 は, 界面き裂は考慮しなくても問題ない（界面破壊に対 して安全側となる）と考えられ，供試体も界面き裂がな いものを対象として以後の考察を行うこととする。

\section{5 指標 $\boldsymbol{\alpha}$ のパラメー夕解析とモデル化}

温度变化を受ける場合の樹脂材端部の応力集中 (case $\mathrm{I}^{\prime}$ ), 曲げを受ける場合のモルタルのひび割れ近傍の応 力集中 (case $\Pi^{\prime}$ ) を対象として, 指標 $\alpha$ の支配パラメー 夕として考えられる各層樹脂材の弾性係数を用いたパラ メー夕解析を行った。このとき解析に用いた層間せん断 ばね定数は, 応力拡大係数 $K_{2}$ のパラメー夕解析之同様 に式 (11)，(12) に示した従来の研究 ${ }^{2}$ より得られた各 層の弾性係数によりモデル化したものを用いた。各材料 定数, 供試体寸法等も表-1 および表-2 ならびに図-6 に示したものを用い，先にも述べたように界面き裂は考 慮しないモデルを用いて解析を行った。

まず, 各層樹脂材の弾性係数を 5000 30000 kgf/ $\mathrm{cm}^{2}$ まで $5000 \mathrm{kgf} / \mathrm{cm}^{2}$ ピッチで変化させ, 指標 $\alpha$ の 変化を調べた。図-17 (a), (b) に2, 3 層目の弾性係数 を一定とし, 1 層目弾性係数 $E_{1}$ を変化させたときの指 標 $\alpha$ の変化, 1,3 層目の弾性係数を一定とし, 2 層目弾性 係数 $E_{2}$ を変化させたときの指標 $\alpha$ の変化, 1,2 層目の 弾性係数を一定とし, 3 首目弾性係数 $E_{3}$ を変化させた ときの指標 $\alpha$ の変化を温度変化を受ける場合および曲げ を受ける場合のそれぞれについて示す。ここでは, 界面で はがれないという力学的要求性能に対する選定条件であ る指標 $\alpha<1.0$ を考虑せずに, 指標 $\alpha$ 之各層の弾性係数の 関係を定性的に評価すると以下のようにまとめられる。

(1) 1 層目弾性係数の感度は, 温度変化を受ける場合 は, 感度は小さいが負の相関が認められる。一方, 曲げ を受ける場合は，樹脂材の弾性係数 $E_{1}$ が大きくなるほ どその感度は小さくなる傾向があり, 温度変化を受ける 
場合と異なり, 全体的には正の相関が認められる。した がって, 界面ではがれにくい材料選定を考える際は, 温 度変化を受ける場合に対しては, 1 層目弾性係数を大き く，曲げを受ける場合は小さくすればよいという結論に 至る。

(2) 2 層目弾性係数の感度は, 温度変化を受ける場合, 曲げを受ける場合とも正の相関が見られる。指標 $\alpha$ に対 する感度は温度変化を受ける場合のほうが大きくなって おり, また 1 層目の樹脂材の弾性係数とその感度を比較 すると両方の case とも 2 層目の感度のほうが大きく なっているのがわかる。したがって, 1 層目の弾性係数 より 2 層目の弾性係数を変化させたほうが指標 $\alpha$ には有 効に働くと考えられる。

(3) 3 層目の弾性係数も 2 層目之同様に正の相関がみら れる。1, 2 層目の弾性係数と指標 $\alpha$ に対する感度を比較 すると, 温度変化を受ける場合は $E_{2}>E_{3}>E_{1}$ という関 係があり, 曲げを受ける場合は $E_{3}>E_{2}>E_{1}$ という関係 がある。

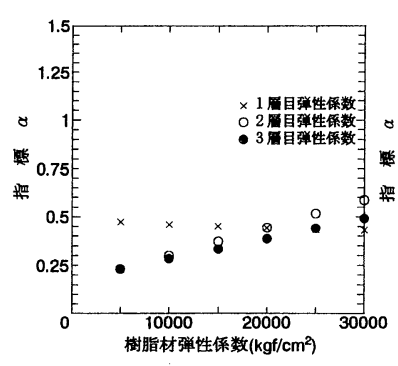

（a ）温度変化を受ける場合 (case I')

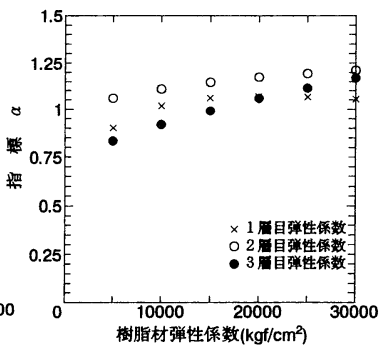

（ｂ）曲げを受ける場合 (case II')
図-17 指標 $\boldsymbol{\alpha}$ に対する各層弾性係数の感度

以上のことから, 感度の大小はあるものの各層の樹脂 材弾性係数は，材料設計を考える上で重要なパラメー夕 となっていることがわかる。

さらに，以上で示したパラメー夕解析結果を用い，各 case について指標 $\alpha$ を各層樹脂材弾性係数で次式のよ うにモデル化し，考察を行った。

(case $1:$ 温度変化を受ける場合-樹脂材端部)

$$
\begin{aligned}
\alpha_{T}= & -3.233 \times 10^{-6} E_{1}+1.223 \times 10^{-5} E_{2}+8.991 \\
& \times 10^{-6} E_{3}+2.020 \times 10^{-1} \\
& (\text { 相関係数 } r=0.9618)
\end{aligned}
$$

(case 2 : 曲げを受ける場合一モルタルのひび割れ近 傍)

$$
\begin{aligned}
\alpha_{L}= & 3.384 \times 10^{-6} E_{1}+4.780 \times 10^{-6} E_{2}+1.192 \\
& \times 10^{-5} E_{3}+7.449 \times 10^{-1} \\
& (\text { 相関係数 } r=0.8432)
\end{aligned}
$$

すなわち, 温度变化を受ける場合は, 1 層目弾性係数 に負の相関がみられ指標 $\alpha_{T}$ に対する感度は $E_{2}>E_{3}>$
$E_{1}$ という関係がある。したがって, 1 層目弾性係数を大 きく, とくに 2 層目の弾性係数を小さくすれば指標 $\alpha_{T}$ に有効に㗢くと考えられる。一方, 曲げを受ける場合の 指標 $\alpha_{L}$ に対する各層樹脂材の弾性係数の感度には, $E_{3}$ $>E_{2}>E_{1}$ という関係がある。とくに 3 層目の感度が大 きく, 3 層目の弾性係数を変化させれば指標 $\alpha_{L}$ に有効 に働くと考えられる。

\section{4. 力学的指標に基づく積層化樹脂材 の材料設計}

\section{1 破壊力学に基づく材料選定指標}

ここでは, 界面にき裂が生じたとしてその後のき裂進 展および界面破壊を考慮した材料選定指標として, 破壊 力学的観点からの力学的材料選定指標を考案する。対象 とするパラメータとしては応力拡大係数とした。

3. では，樹脂材選定の対象となる荷重条件と界面き 裂位置の組み合わせとして 4 case を取り上げ，その 内, 温度変化を受ける場合の樹脂材端部に生じる界面き 裂先端部分の応力集中 (case I) と曲げを受ける場合の モルタルのひび割れ近傍の界面き裂先端部分の応力集中 (case II)の 2 case を取り上げた。ここでもこの 2 case を対象とした材料選定を考える。

また, 応力拡大係数 $K_{1}, K_{2}$ のうち, 荆離方向の界面 破壊は考えず, 本研究で対象とする界面せん断方向の破 壊に関連する力学的指標となり得る $K_{2}$ を材料選定指標 のパラメータとして取り上げた。応力拡大係数のもつ dimension は $\mathrm{kgf} \bullet \mathrm{cm}^{-3 / 2}$ であり, 指標として考える うえで有効なパラメータで無次元化する必要がある。そ こで, 次式に示すように応力の dimension に対して は, 温度変化を受ける場合は母材の熱応力 $\sigma_{T} 0$, 曲げを 受ける場合は母材の平均せん断応力 $\tau_{L} 0$ を無次元化パ ラメータとし, 長さの dimension に対してはき裂長さ を無次元化パラメータとした。ここで, 温度変化を受け る場合は $\Phi_{T}$, 曲げを受ける場合は $\Phi_{L}$ と表し, 積層化樹 脂材の破壊力学的指標とした。

$$
\begin{aligned}
& \left(\text { case I ) } \Phi_{T}=W_{T} \frac{K_{2}}{\sigma_{T 0} \sqrt{\pi a}}\right. \\
& \left(\text { case II ) } \Phi_{L}=W_{L} \frac{K_{2}}{\tau_{L 0} \sqrt{\pi a}}\right.
\end{aligned}
$$

ただし，

ここで,

$$
\sigma_{T 0}=E_{0} \alpha_{0} \Delta t, \quad \tau_{L 0}=\frac{P_{L}}{2 A_{0}}
$$

$a:$ き裂長さ $(\mathrm{cm})$

$E_{0}$ : 母材の弾性係数 $\left(\mathrm{kgf} / \mathrm{cm}^{2}\right)$

$\alpha_{0}$ : 母材の線膨張係数 $\left(1 /{ }^{\circ} \mathrm{C}\right)$

$\Delta t:$ 温度変化量 $\left({ }^{\circ} \mathrm{C}\right)$

$P_{L}:$ 曲げ荷重 (kgf) 
$A_{0}:$ 母材の断面積 $\left(\mathrm{cm}^{2}\right)$

とする。また， $W_{T}, W_{L}$ は, 温度変化, 曲げを受ける 場合を相対的に比較するときの重みとして考え，次式で 表す。

$$
W_{T}=\frac{\sigma_{T 0}}{\sigma_{T 0}+\tau_{L 0}}, \quad W_{L}=\frac{\tau_{L 0}}{\sigma_{T 0}+\tau_{L 0}}
$$

ここで, 2. の応力搪大係数 $K_{2}$ のパラメー夕解析結果 を用い, 指標 $\Phi_{T}, \Phi_{L}$ を各層樹脂材の弾性係数で次式の ようにモデル化し, 各層弾性係数の定性的な評価を行っ た。

$$
\begin{aligned}
\Phi_{T}= & 3.580 \times 10^{-6} E_{1}+3.268 \times 10^{-6} E_{2}+1.422 \\
& \times 10^{-6} E_{3}-5.734 \times 10^{-3} \\
& (\text { 相関係数 } r=0.9747) \\
\Phi_{L}= & 1.659 \times 10^{-6} E_{1}+1.276 \times 10^{-6} E_{2}+7.849 \\
& \times 10^{-7} E_{3}+8.325 \times 10^{-3} \\
& (\text { 相関係数 } r=0.9625)
\end{aligned}
$$

上式より, 指標 $\Phi_{T}$ に関しては, 各層の樹脂材の弾性 係数の感度は $E_{1}>E_{2}>E_{3}$ という関係があることがわか る。各層の樹脂材弾性係数の感度を比で表すと約 $10: 9$ : 4 という関係があり, 指標 $\Phi_{T}$ に対しては, 特に 1 層 目弾性係数および 2 層目弾性係数を変化させると有効で あると考えられる。また指標 $\Phi_{L}$ に関しても $\Phi_{T}$ 之同様 に各層樹脂材の弾性係数の感度は $E_{1}>E_{2}>E_{3}$ となって おり, それらの感度を比で表すと約 $10: 7.5: 4.5$ とい う関係がある。したがって, 指標 $\Phi_{L}$ に対しては特に 1 層目の弾性係数を変化させると有効であることがわか る。

次に, パラメー夕解析結果より得られたそれぞれの樹 脂材の組み合わせのもとでの指標 $\Phi_{T}$ と $\Phi_{L}$ の関係を 図-18に示す。これより，指標 $\Phi_{T}$ と $\Phi_{L}$ の間には明確な 相関が見られ，ほぼ線形関係にある。また, 指標 $\Phi_{T}$ の ほうが大きな值をとり, 樹脂材の弾性係数の変化にとも なう指標の変化量も大きくなっている。したがって, 界 面き裂を考慮し，指標 $\Phi$ を用いた材料選定を考える場 合, 温度変化を考慮した材料選定が重要となってくる。 ここで, 界面ではがれないという力学的要求性能に対す る選定条件として指標 $\Phi<0.1$ を設定し, 図-18にその 適用範囲を示した。選定条件の設定に対しては今後実験 等を通してさらに検討を行う必要はあるが，ここでは， このような選定条件を設けることで指標の傾向および材 料設計の検討が行えると考えた。その結果, 指標 $\Phi$ の值 が図-18 の左下の点線内の範囲にあるものが界面ではが れないという力学的要求性能に対する材料選定に対し, 有効な組み合わせであると考えられる。したがって, 破 壊力学に基づく選定指標 $\Phi$ を用いた材料選定としては式 (20)，(21）を用い，両式でともに指標 $\Phi<0.1$ を満たす 組み合わせを考えればよいことになる。

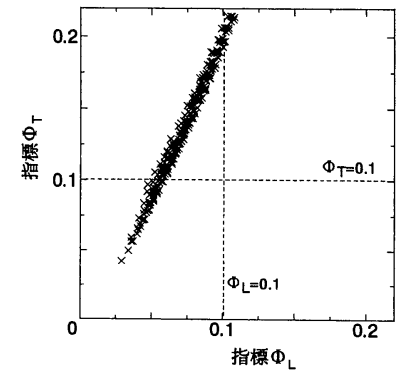

図-18 指標 $\Phi_{T}$ と指標 $\Phi_{L}$ との関係

次に, 指標 $\Phi$ を用いた材料選定例として, 指標 $\Phi$ の界 面で破壊しないという力学的要求性能に対する選定条件 を指標 $\Phi<0.1$ 之設定し, 材料選定の対象となる樹脂材 の弾性係数の範囲を 5000 30 $000 \mathrm{kgf} / \mathrm{cm}^{2}$ として, $5000 \mathrm{kgf} / \mathrm{cm}^{2}$ ごとに各層の弾性係数を変化させ, 力学 的要求性能を満足する各層樹脂材の弾性係数の組み合わ せを表-13 に示した。その結果, 1, 2 層目弾性係数は, $20000 \mathrm{kgf} / \mathrm{cm}^{2}$ までの範囲, 3 層目弾性係数は 30000 $\mathrm{kgf} / \mathrm{cm}^{2}$ までが適用範囲となり, 1,2 層目の弾性係数 が大きいほど材料選択の範囲が狭くなっているのがわか る。したがって, 指標 $\Phi$ を用い, 界面破壊を考虑した材 料選定を考える際には，1，2 層目の弾性係数が重要と なってくると考えられる。

表一13 指標 $\boldsymbol{\Phi}$ による材料選定例

\begin{tabular}{c|c|c}
\hline$E_{1}\left(\mathrm{kgf} / \mathrm{cm}^{2}\right)$ & $E_{2}\left(\mathrm{kgf} / \mathrm{cm}^{2}\right)$ & $E_{3}\left(\mathrm{kgf} / \mathrm{cm}^{2}\right)$ \\
\hline 5000 & $5000 \sim 10000$ & $5000 \sim 30000$ \\
& 15000 & $5000 \sim 25000$ \\
\hline 10000 & 20000 & $5000 \sim 15000$ \\
\hline & 5000 & $5000 \sim 30000$ \\
& 10000 & $5000 \sim 25000$ \\
\hline \multirow{2}{*}{15000} & 15000 & $5000 \sim 10000$ \\
\hline 20000 & 5000 & $5000 \sim 25000$ \\
\hline & 10000 & $5000 \sim 10000$ \\
\hline
\end{tabular}

\section{2 指標 $\alpha$ を用いた材料選定}

ここでは, 前述の指標 $\alpha$ を用いた材料選定について検 討を行う。3. では, 従来の研究で用いられた指標 $A \tau$ の限界值を $A \tau_{c}$ 之設定し, 指標 $\alpha=A \tau / A \tau_{c}$ なる積層 化樹脂材の力学的材料選定指標を提案し, 界面ではがれ ないという力学的要求性能に対し, 指標 $\alpha<1.0$ となる 樹脂材の組み合わせを考えれば材料選定上有効であると 考えた。

温度变化を受ける場合（指標 $\alpha_{T}$ ) と曲げを受ける場 合（指標 $\alpha_{L}$ ) の供試体間での指標 $\alpha$ の関係を調べるた 
め, 3. で行ったパラメー夕解析より得られた指標 $\alpha_{T}$ と 指標 $\alpha_{L}$ との関係を図-19に示す。両者の関係は, 図-18に示した指標 $\Phi_{T}$ と $\Phi_{L}$ の関係のような明確な線 形関係は認められず，相関性も小さい。また，曲げを受 ける場合のほうが指標の值は大きくなり, 指標 $\alpha$ を用い た材料設計では曲げを考慮した材料選定が重要となって

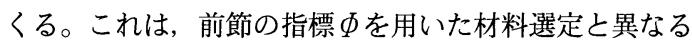
傾向を示している。

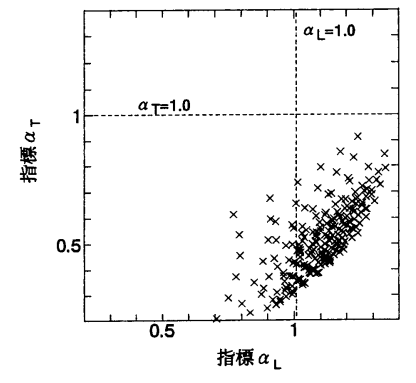

図-19 指標 $\boldsymbol{\alpha}_{T}$ と指標 $\boldsymbol{\alpha}_{L}$ との関係

ここで, 選定条件となる指標 $\alpha<1.0$ を導入すれば 図-19に示したように適用範囲が示され，図中の左下の 点線内の樹脂材の組み合わせが材料選定では有効とな る。したがって, 指標 $\alpha$ を用いた材料選定では, 式 (15)，(16）を用い，両式でともに指標 $\alpha<1.0$ を満たす 組み合わせを考えればよい。

次に前節と同様，指標 $\alpha$ を用いた材料選定例を示す。 界面で破壊しないという力学的要求性能に対し, 選定条 件として指標 $\alpha<1.0$ を設定し, 積層化樹脂材の材料選 定の対象となる各層の樹脂材の弾性係数の範囲を 5000 〜30000 kgf/ $/ \mathrm{cm}^{2}$ として, $5000 \mathrm{kgf} / \mathrm{cm}^{2}$ ごとに各層の 弾性係数を変化させ, 力学的要求性能を満足する各層樹

\section{表一14 指標 $\boldsymbol{\alpha}$ を用いた材料選定例}

\begin{tabular}{c|c|c}
\hline$E_{1}\left(\mathrm{kgf} / \mathrm{cm}^{2}\right)$ & $E_{2}\left(\mathrm{kgf} / \mathrm{cm}^{2}\right)$ & $E_{3}\left(\mathrm{kgf} / \mathrm{cm}^{2}\right)$ \\
\hline 5000 & 5000 & $5000 \sim 20000$ \\
& $10000 \sim 20000$ & $5000 \sim 15000$ \\
\hline 10000 & $25000 \sim 30000$ & $5000 \sim 10000$ \\
\hline 15000 & 5000 & $5000 \sim 15000$ \\
& $10000 \sim 15000$ & $5000 \sim 10000$ \\
\hline 20000 & $20000 \sim 30000$ & 5000 \\
\hline 25000 & 5000 & $5000 \sim 10000$ \\
& $10000 \sim 30000$ & 5000 \\
\hline 30000 & 5000 & $5000 \sim 10000$ \\
& $10000 \sim 15000$ & 5000 \\
\hline & 5000 & $5000 \sim 10000$ \\
\hline & $10000 \sim 15000$ & 5000 \\
\hline & 5000 & $5000 \sim 10000$ \\
\hline
\end{tabular}

脂材の弾性係数の組み合わせを表-14 に示した。その結 果, 3 層目樹脂材の弾性係数は $10000 \mathrm{kgf} / \mathrm{cm}^{2}$ までの 範囲, 1 層目と 2 層目の弾性係数については 30000 $\mathrm{kgf} / \mathrm{cm}^{2}$ までの範囲が適用範囲となり, 3 層目の材料選 定の範囲が狭くなっている。したがって, 指標 $\alpha$ を用い て界面破壊を考慮した材料選定を考える際は，特に 3 層 目の樹脂材の弾性係数の選択が重要となると考えられ る。

\subsection{2 つの指標の結合と最適材料設計手法の検討}

樹脂材端部およびモルタルのひび割れ近傍の応力集中 または界面き裂先端の応力集中部分での界面破壊を考え る場合, 応力集中部の形状として, 応力の絶対值と応力 勾配が問題となる ${ }^{13)}$ 。したがって, 解析において求め られる応力集中部の応力最大值を用いた評価は有効でな いと考えられ, 本研究では破壊力学の観点から指標 $\Phi$ を 提案し, また別の観点から従来の研究で用いられた指標 を用いて指標 $\alpha$ を考案した。指標 $\Phi$ は, 破壊力学のパラ メータとして応力搪大係数をパラメータとして用いてお り, 応力拡大係数が応力集中部における応力分布形状を 表すものとしてぜい性破壊, 疲労破壊に対するパラメー 夕として用いられることから，指標 $\Phi$ は界面破壊に関し て有効に利用できる指標であると考えられる。その物理 的意味を考えると, 応力拡大係数がもつ dimension は $\mathrm{kgf} \cdot \mathrm{cm}^{-3 / 2}$ であるが, 応力拡大係数が荷重状態および 応力集中部形態などに関する応力集中特性を示すパラ メータであることから応力場に基づく界面き裂を対象と した指標である。これに対し，指標 $\alpha$ は応力集中部にお ける応力の絶対值とその勾配の両方を評価できる指標と して考案されたものであり, 本研究ではその指標 $\alpha$ に限 界值 $A \tau_{c}$ を考慮して指標 $\alpha$ を提案した。その物理的意 味としては, 層間せん断応力分布図において, 応力分布 とその横軸が囲む面積を $A \tau$ とおいたことから, 界面破 壊に対するエネルギー的評価を行う指標 $\alpha$ であると考え られる。したがって, 両者の持つ物理的意味に相違があ ることから $2 つ$ つ指標を直接結び付けることは困難であ り, また現時点で両者の優劣を決めることも難しい。し かし， 2 つの指標を同時に考慮することにより応力的評 価およびエネルギー的評価を同時に取り入れることがで き, 界面破壊を対象とした積層化樹脂材の材料選定に有 効であると考えられる。

各荷重条件における両指標の関係を見るため, 樹脂材 の弾性係数の範囲を $5000 \sim 30000 \mathrm{kgf} / \mathrm{cm}^{2}$ と設定して, 温度变化を受ける場合の両指標間の関係を図 -20 に, 曲 げを受ける場合の両指標間の関係を図一21にそれぞれ示 す。これより, 温度変化を受ける場合のほうが指標間で の值の変化が大きくみられ, 曲げを受ける場合は, 各供試 体が示す值の範囲は小さくなっている。ここで, 界面で 
破壊しないという力学的要求性能に対する選定条件とし て, 指標 $\Phi<0.10$, 指標 $\alpha<1.0$ を適用すれば図-20, 図-21 中の左下の点線内の樹脂材の組み合わせが選定上有効で あることになる。これより, 温度変化を受ける場合は指 標 $\Phi か ゙$ 選定条件として支配的となっており, 一方, 曲げ を受ける場合は指標 $\alpha$ が選定条件として支配的となって いる。したがって, 温度変化の影響は界面き裂を考慮し た場合に重要となり, また，曲げの影響はき裂発生前の 状態を考慮した材料選定の際に重要となってくる。

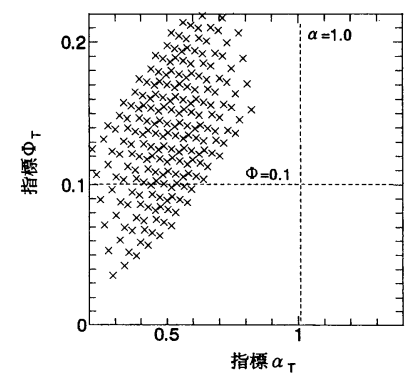

図一20 指標 $\boldsymbol{\alpha}_{T}$ と指標 $\boldsymbol{\Phi}_{T}$ との関係

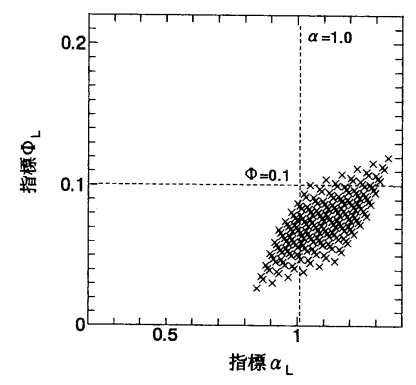

図-21 指標 $\boldsymbol{\alpha}_{L}$ と指標 $\boldsymbol{\Phi}_{L}$ との関係

4.2 および 4.3 で，それぞれの指標を用いた材料選定 例を示したが, ここで，その結果を比較すると，指標 $\Phi$ のみを用いた材料選定では 1,2 層目の弾性係数を特に 小さくしたほうが界面で破壊しないという力学的要求性 能に対して有効であるのに対し，指標 $\alpha$ を用いた材料選 定では, 3 層目の弾性係数を特に小さくしたほうが有効 であるという結果となっており，両者の傾向は異なって いる。したがって，先に述べたようにその物理的意味を 考えると応力的評価とエネルギー的評価では, その材料 選定に異なる傾向が現れると考えられる。それゆえ, 両 指標の選定条件を満たす材料選定を考えれば異なる $2 つ$ の観点からの評価を考慮した材料選定を行うことがで き, さらに有効な材料選定を行うことができると考え る。 4.2 および 4.3 で示した材料選定により力学的要求 性能を満足するとして得られた樹脂材の組み合わせの 内, 両指標の選定条件を同時に満足する樹脂材の組み合
わせを表-15に示す。その結果, 界面ではがれないとい う力学的要求性能に対して力学的に最適な樹脂材の組み 合わせは, 弾性係数が $15000 \mathrm{kgf} / \mathrm{cm}^{2}$ 以下の樹脂材を 用いて行い，表-15に示す組み合わせの中から選択すれ ばよいことになる。

\section{表-15 2 つの指標を統合した材料選定例}

\begin{tabular}{c|c|c}
\hline$E_{1}\left(\mathrm{kgf} / \mathrm{cm}^{2}\right)$ & $E_{2}\left(\mathrm{kgf} / \mathrm{cm}^{2}\right)$ & $E_{3}\left(\mathrm{kgf} / \mathrm{cm}^{2}\right)$ \\
\hline 5000 & 5000 & $5000 \sim 20000$ \\
& $10000 \sim 20000$ & $5000 \sim 15000$ \\
\hline \multirow{2}{*}{10000} & 5000 & $5000 \sim 15000$ \\
& $10000 \sim 15000$ & $5000 \sim 10000$ \\
\hline 15000 & 5000 & $5000 \sim 10000$ \\
& 10000 & 5000 \\
\hline 20000 & 5000 & $5000 \sim 10000$ \\
\hline
\end{tabular}

最終的には, 材料学的要求性能もしくは他の力学的要 求性能を考慮し, 指標 $\Phi$, 指標 $\alpha$ の選定条件を満足する 積層化樹脂材の樹脂材の組み合わせの中から, 他の選定 要因を考虑して樹脂材を選択すれば力学的にも材料学的 にも最適な積層化樹脂材の材料設計を行うことができる と考えられる。

\section{5. 結語}

本研究では, コンクリート構造物の補修に用いられる 積層化樹脂材について, 力学的な機能性を評価するため の材料選定指標を確立し, 合理的な材料設計を行うこと を目的として界面応力解析を行い, 界面き裂の進展にと もなう界面破壊を考慮した材料選定指標を提案した。そ して, 破壊力学的観点からの力学的挙動に基づく指標と 界面の層間応力に着目した力学的挙動に基づく指標の 2 つを結合した材料設計を行えばさらに合理的な材料設計 が行えることを確認した。以下に本研究で得られた主な 結果をまとめて示す。

（1）積層化樹脂材が温度変化および曲げを受ける場 合の界面における力学的挙動を評価するための解析手法 として 2 次元 FEM 解析に界面特性を表すモデルとして Bond-link 要素を組み込んだ手法の有効性を明らかに した。

（2）積層化樹脂材界面でのき裂進展および界面破壊 に関する力学的挙動の評価に破壊力学の適用を試み，そ のパラメータである応力拡大係数, エネルギー解放率を 算出した。その結果, 温度変化を受ける場合は樹脂材端 部の界面き裂近傍, 曲げを受ける場合はモルタルのひび 割れ近傍の界面き裂近傍の応力集中が材料選定上支配的 となると考え, その評価パラメータとして, 界面せん断 方向破壊の支配パラメー夕と考えられる応力拡大係数 $K_{2}$ を用いることが妥当であることを明らかにした。ま 
た，各層樹脂材の弾性係数の応力拡大係数に及ぼす影響 をパラメー夕解析によって明らかにし， $K_{2}$ に対する各 層樹脂材の弾性係数の感度は, $E_{1}$ ( 1 層目弾性係数 $)>E_{2}$ $(2$ 層目弾性係数 $)>E_{3}(3$ 層目弾性係数) という関係があ ることを示した。

(3) 従来の研究で考案された指標 $A \tau$ の限界値に関 する静的破壊試験を実施し, 指標 $A \tau$ の限界值 $A \tau_{c}$ と 樹脂材の弾性係数の間に相関が認められることを明らか にした。そこで, 従来の指標 $\mathrm{A} \tau$ にその限界值 $A \tau_{c}$ を 考慮した指標 $\alpha=A \tau / A \tau_{c}$ を提案し, 各層樹脂材の弾性 係数が指標 $\alpha$ に対する重要な支配パラメータであること を示した。すなわち, 温度変化を受ける場合は, 1 層目 の弾性係数之指標 $\alpha$ の間に負の相関がみられ，また，2 層目弾性係数に大きな相関が認められることから，1 層 目の弾性係数を大きくし, 特に 2 層目弾性係数を小さく すれば指標 $\alpha$ に有効に働くことを示した。一方，曲げを 受ける場合は各層の弾性係数は正の相関を示し, 特に 3 層目の弾性係数の感度が大きいことから, 3 層目の弾性 係数を小さくすれば指標 $\alpha$ に有効に働くことを示した。

(4) 応力拡大係数 $K_{2}$ を用いた材料設計指標 $\Phi$ を提 案し, 界面で破壊しないという力学的要求性能に対する 指標 $\Phi$ 用いた材料選定について検討を行った。指標 $\Phi$ を用いた材料選定では, 特に 1,2 層目の弾性係数の選 定が重要となってくることを明らかにした。さらに, 指 標 $\Phi$ に対する選定条件を設定し，具体的な材料選定例を 示した。

（5）界面で破壊しないという力学的要求性能に対 し, 指標 $\alpha<1.0$ となる選定条件のもとで指標 $\alpha$ を用い た材料選定例を示した。その結果, 指標 $\alpha$ を用いた材料 設計では, 3 層目の弾性係数の選定が重要となることを 明らかにした。

（6）樹脂材界面の破壊を支配する 2 つ指標 $\Phi$ （界 面での破壊力学に基づく指標), $\alpha$ (層間応力の限界值に 基づく指標）が有する物理的意味に基づいて両者を結合 した材料選定を行うことで応力的な評価, エネルギー的 な評価を同時に考慮することができ，より合理的な材料 設計が行えることを示した。すなわち, 樹脂材界面で破
壊しないという力学的要求性能に対する材料選定に対し て両指標の選定条件を同時に考慮することにより, 材料 選択の幅が小さくなることを明らかにすることによって 合理的な材料選定が行える具体例を示した。

[謝 辞] 本研究の実施にあたり, 種々の援助を頂い た(㑣)サンキット 藤岡英博氏に紙上を借りて感謝の意を 表します。

\section{参考 文 献}

1) 材料設計小委員会: 関西道路研究会道路橋調查委員会材 料設計小委員会報告書, 1986

2）宮本文穂・森川英典・林村聡文・若原直樹 : コンクリー 卜補修用積層化樹脂材の力学的挙動之材料設計に関する 基礎的研究, コンクリート工学論文集, 第 5 卷, 第 2 号, pp. 49 63, 1994. 7

3）阪神高速道路公団・日本材料学会: コンクリート構造物 の表面保護工便覧(案)同解説, 1989. 3

4) 宮川豊章：樹脂：用途がひろがる補修・補強用材料, pp. 43〜 47, 土木学会誌, 1985.11

5）森田司郎・藤井 栄: 有限要素法による鉄筋コンクリー 卜構造のせん断解析手法, $\mathrm{RC}$ 構造のせん断問題に対す る解析的研究に関するコロキウム論文集, JCI-C1, pp. 77 98, 1982. 6

6) 阿山泰久・宮本文穗・中西 誉・若原直樹 : コンクリー 卜補修用皘層化樹脂材の材料設計に関する基礎的研究, 土木学会年次学術講演会講演概要集, Vol. 49, No. 5 , pp. 727 729, 1994. 9

7) 石田 誠: き裂の弾性解析之応力拡大係数, 培風館, 1976. 6

8）結城良治・許 金泉：界面き裂の力学, 生産研究, 42-8, pp. 508 514, 1990

9）結城良治: 界面の力学, 培風館, 1992.7

10) Commininou, $M$ : The Interface Crack, J. Apple. Mech., 44, pp. 631-637, 1977

11）宮本文穂・森川英典・木村聡文・若原直樹・藤岡英博： 積層化樹脂材の力学的挙動と材料選定指標の確立, 建設 工学研究所報告, 第 33 号, 1991.12

12）(社) 土木学会 : 構造工学シリーズ 1, 構造システムの最 適化 理論と応用 , 1988.9

13）西田正孝:応力集中, 森北出版, 1967.9

（原稿受理年月日 : 1995 年 6 月 16 日） 


\section{FEM Analysis of Interface Behaviors of Multilayered Resin Material and Its Application to Optimum Design \\ By Ayaho Miyamoto, Yasuhisa Ayama, Homare Nakanishi and Naoki Wakahara}

Concrete Research and Technology, Vol. 7, No. 1, Jan. 1996

Synopsis In order to establish a practical design concept of the multilayered resin materials for repair of deteriorated concrete structures, it is important to evaluate the mechanical behaviors of interface among layers and concrete surface during various stages under service conditions as well as providing adequate chemically and physically stable bonding between them. The aim of this particular research is not only to develop a few indexes which represent their mechanical behaviors based on 2-D FEM analysis which considered the linear elastic fracture mechanics, but also to demonstrate the feasibility of applying the proposed indexes to optimum design of multilayered resin materials for repair of deteriorated concrete structures.

Keywords : concrete structures, repairs, multilayered resin materials, finite element method, interfacial stress, stress intensity factor, material design 